\title{
A STUDY OF SOME BIOLOGICAL, ANATOMICALAND RELATED ENVIRONMENTAL FEATURES OF NUTRIA/MYOCASTOR COYPUS/ FROM THE TERRITORY OF STARA ZAGORA REGION
}

\author{
Radoslav MIHAYLOV ${ }^{1}$, Rosen DIMITROV ${ }^{2}$, Rumen BINEV ${ }^{3}$, \\ Kamelia STAMATOVA-YOVCHEVA ${ }^{2}$ \\ 'Department of Morphology, Physiology and Animal Nutrition, faculty of Agriculture, \\ Trakia University, 6000 Stara Zagora, Bulgaria \\ ${ }^{2}$ Department of Veterinary Anatomy, Histology and Embryology, \\ Faculty of Veterinary Medicine, Trakia University, 6000 Stara Zagora, Bulgaria \\ ${ }^{3}$ Department of Internal Non-Infectious Diseases, Faculty of Veterinary Medicine, \\ Trakia University, 6000 Stara Zagora, Bulgaria
}

Geliş Tarihi: 09.02.2017 Kabul Tarihi: 22.04.2017

Makale Kodu: 290937

\begin{abstract}
The nutria (Myocastor coypus) belongs to the class of Mammals, Rodents order, family Myocastoridae. It leads a semiaquatic lifestyle and can be seen around rivers, lakes and marshes. Nutria is the biggest rodent in Bulgaria. It lives mainly along the rivers of southeastern Bulgaria. The animal's body is cylindrical in shape, with relatively large head and short ears. The peak of the face is blunted with clearly visible teeth, colored in bright orange. Nutrias are mostly herbivores. Their role is to spread diseases such as equine encephalomyelitis, leptospirosis, hemorrhagic septicemia (Pasteurellosis), paratyphoid and salmonellosis. The aim of the study is to examine the impact of nutria on the environment on the territory of Stara Zagora region, and some of its biological and anatomical features. In some territories of Stara Zagora were found traces of life activity of nutria, as entrances of shelters, footprints of thoracic and pelvic limbs, and feces. Nutrias have not permanent habitats. In the study we found no evidence of damage on the environment. The study showed that the result of the vital activity of nutrias is rather positive, concerning the cleaning of the water areas of vegetation. We found that the thoracic and pelvic limbs have five fingers. The difference between the volume of the nutria cranial cavity and these of the jackal and fox is provoked by the differences in the type of their food and lifestyle.
\end{abstract}

Keywords: Nutria, anatomy. 


\section{INTRODUCTION}

Nutria (Myocastor coypus) belongs to the class of Mammals, Rodents order, family Myocastoridae (1). In many countries, this rodent is considered to be a pest because of its negative impact on the ecosystems, different grain crops and irrigation systems $(2,3)$. For these reasons nutria is included in the list of 100 of the most harmful invasive species in the world (4).

Nutria leads a semiaquatic lifestyle and meets around rivers, lakes and marshes. The natural species range covers the plateau Patagonia in South America (5).

At the beginning of the last century it lived in Chile, in the northern parts of Argentina, Bolivia, Paraguay, and southern Brazil. As a result of escapes and releases from fur farms, wild populations of the species are currently found in Europe, North America, North Asia, Japan, East Africa and the Middle East (1).

In Bulgaria nutria was introduced for free lifestyle in the Mandrensko lake and the reserve "Arkutino" in 1953 (6). In the inland was registered as a living wild anaimal around Maritsa River, Plovdiv (7), River Sazliika around Radnevo (8) and near Harmanli (9). Nutria is more widespread than known until now (10). It is established in 39 UTM square in Bulgaria, the catchment areas of the rivers Maritsa and Tundzha and the rivers flowing into the Black Sea.

For the first time nutria are imported in Europe (Germany) from their homeland South America in 1926. In Bulgaria nutria got shelter in the hunting enterprise Sherba in 1948. The exceptional interest in this animal at the time was due to best results in farms breeding. In the country in many places are organized farms for nutria, but due to the decline of this activity, the nutria find themselves in freedom and now inhabit a number of water bodies in Bulgaria (11).
The weight of male nutria in the nature reaches 8 to $10 \mathrm{~kg}$ and that of the females up to $7.5 \mathrm{~kg}$. The length of the body is up to $65 \mathrm{~cm}$, and that of the tail up to $45 \mathrm{~cm}$. The limbs possess 5 fingers. Pelvic limbs carry four inner fingers which are interconnected with palmate and the fifth is free $(11,12)$.

The coloration of nutria is dark gray with metallic glint. It inhabits mainly along the rivers of the southeastern Bulgaria. It inhabits the water basins with marsh vegetation. Nitria constructs their holes above the water level. It is active at night and go out to eat mostly plant foods, so it dwells heavily overgrown ponds. In her food are included marsh and water plants, seeds, fruits and the green mass of crops surrounding the bassins. Nutria does not eat fish, which makes it suitable for breeding in fish farms. Animal food, which it accepts consists of clams and small molluscs. Sexual maturity occurs in the fifth or sixth month of postnatal development. Nutria pregnancy lasts 120-130 days, giving birth to 1 to 13 smaller, but more often 5 or 6 . They start seeing the first day, suck up to the tenth week, a few days after birth; they begin to feed with plant food (11) (Figure 1).

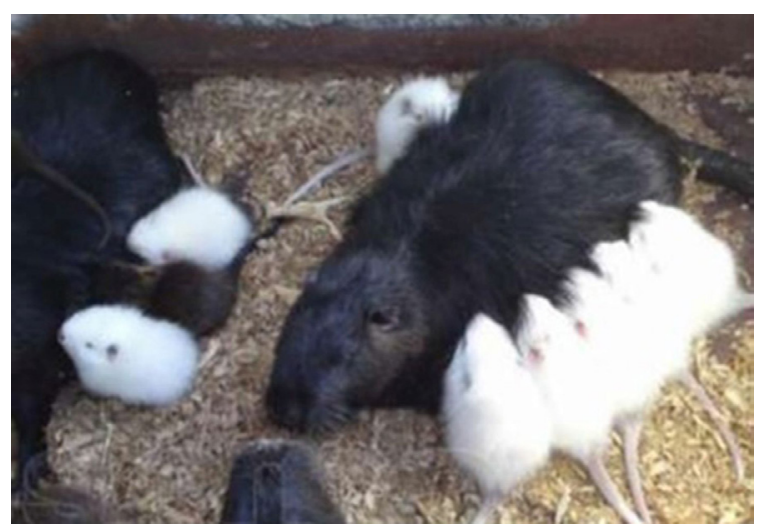

Figure 1: Nutria with its small babies (15)

Nutria is the biggest rodent in Bulgaria. The pelvic limbs are with five fingers and are longer than pectorals that have four fingers 
(13). The body is covered with coarse and fine soft hairs and tail - with rare hairs and the skin is flaky. Its coloring is gray-brown. The total number of teeth in nutria is 20 , as their dental formula is (I $1 / 1, \mathrm{C} 0 / 0, \mathrm{P} 1 / 1$, $\mathrm{M} 3 / 3) \times 2=20$. It lives in the holes with depth 2 to 3 meters, which digs close to the water. Typical device for her semiwater lifestyle is that mammary glands are located high on the side of the body, which facilitates breastfeeding of the small babies (13) (Figure $1)$.

In Bulgaria nutria is included in the list of huntable species. On the coast it is an easy target, but the problem is to discover it. During the day, the hunters look for holes and track, and it comes on the evening. It leaves a mark of its five fingers (14).

Pelvic limbs nutria are more developed compared to the pectoral. Although it looks clumsy on land, nutria is able to move quickly on land over long distances. The ears are small and the eyes are located dorsal to the head. The nose and mouth are with valves (ie they can be closed to prevent the entry of water). Nutrias are able to swim long distances under water (12) (Figure 1).

The animal's body is cyllindric, with relatively large head and short ears. The apex of the face is blunted with clearly visible teeth, colored bright orange, which like many other rodents grow throughout life. The eyes of the animals are located near the forehead that provides excellent vision while swimming (15) (Figure 1).

In the wild, these animals are mainly nocturnal but when keep them in cages they are active at night and during the day. In their natural environment shelters are not permanent because they often change their habitat due to migration, looking for food (15).

Nutrias are mostly herbivores. The structure of digestive canal has the same characteristics as that of other rodents. The stomach is located in the left half of the abdominal cavity. The volume of the stomach is to $500 \mathrm{ml}$ (about $20 \%$ of the total volume of the gastrointestinal tract) (15).

The total length of the intestine is from 10 to 12 times greater than the length of the body. Like rabbits, nutrias have very large cecum (its length is about $50 \mathrm{~cm}$, and its volume is equal to the capacity of the other intestines (15).

Animals do not tolerate the cold weather and therefore they lose appetite and become slow. The optimal ambient temperature for nutria is $15-20{ }^{\circ} \mathrm{C}$. The normal body temperature of Nutria is $37-38{ }^{\circ} \mathrm{C}$, and the respiratory rate is $45-55$ per minute (15).

In the wild, many nutrias live less than 3 years, but in a controlled breeding of the animals, they can live from 15 to 20 years (16).

In the United States, sugar cane and rice are the main crops damaged by nutrias. Moreover, nutrias dig holes in the dikes (17, Evans, 1970). They dig lawn in golf courses, damaging the wooden structures of homes and quays (4).

In Louisiana state, USA the largest wild population of nutria is found. The number of nutria in Southeast Louisiana is 6000 animals per square mile. This large population has received its start in 1937, Avery Island, where a farmer brings small number of nutria, with the aim of breeding and rearing them in a sheltered place for fur. The animals have adapted to their new home and have successfully bred. Hurricane along the coast of Louisiana in 1939 and 1940 caused escape of these animals from several farms in the area. For two years nutrias have been spread to Texas and Mississippi. Nutria population has grown to enormous size and has reached 
to 20 million animals till the end of 1950 . Meantime messages have been appeared, which concern damages from nutria in coastal wetlands $(18,19)$.

Nutrias are economically important to people when their fur and meat provide income. On the other hand, they are considered pests when causing material damage (20).

Nutrias can be infected with some pathogens microorganisms and parasites that can be transmitted to humans and animals. The role of the nutria is to spread diseases such as equine encephalomyelitis, leptospirosis, hemorrhagic septicemia (Pasteurellosis), paratyphoid and salmonellosis. They are host to a number of parasites that cause "Nutria itch" (Strongyloides myopotami and Schistosoma mansoni), of protozoa responsible for giardiasis (Giardia lamblia), tapeworms (Taenia SPP.) and liver fluke (Fasciolosis) (21).

In Britain, where nutrias were imported for fur and meat, were caused major damages to crops and drainage systems. In 1981 was accepted a 10 -year program to capture them alive, which led to the liquidation of nutria in the Great Britain (22).

When examining the habitat of nutria, the paths and entrances of the holes are detected where are found fresh traces that can be used to identify the species. The traces left by the pelvic limbs are characterized by the imprint of the four webbed fingers and the free fifth finger. The trace of the dragging round tail can be seen between the fingerprints of the pelvic limbs. Feces of nutria can be found floating in the water or on the trails (23).

For wild nutria living in Banska River, reported Shterev (24).

Irrigation canals in Pazardzhik village Mokrishte is cleaned in an unconventional way. Nearly 30 years the facility was not cleaned because of lack of funding. Due to the favorable environment in the channel nutrias have settled that have cleaned the equipment. According to the mayor of the village, now in the channel are living, stocks of nutria - large and small (25).

About captured near Stara Zagora nutria "escaper" reported the newspaper "Sega" (26). She was caught in the garden of a suburban pool by specialists of Stara Zagora zoo and placed in the zoo.

The literary analysis shows that nutrias have both positive and negative qualities. They are economically important for people when their fur and meat provide income. On the other hand, they are considered pests when causing damage and as disease vectors. The presented contradictory data on the impact of nutria on the environment, the need to clarify certain anatomical features and insufficient research motivated us to perform this study.

\section{Aim and tasks of the study}

The purpose of this study was to examine the impact of nutria on the environment on the territory of Stara Zagora region, and some of her biological and anatomical features.

To achieve the goal we put the following tasks:

1. To get acquainted with places of habitation of nutria in the Stara Zagora region.

2. To document the presence of nutrias.

3. To investigate and determine the impact of nutria on the environment at places of habitation.

4. To determine the volume of the cranial cavity.

5. To analyze and interpret the the results.

\section{MATERIALS AND METHODS}

Materials: 
The study was conducted on the territory of the lands, close to Stara Zagora: Badeshte village, Pastren village, Petrovo village, Pamukchii village, Knjajevsko village, and near the town of Nova Zagora, for the period from 15/ 04/ 2016 to 25/ 09/2016. We used 15 skulls of nutria from the craniological collection of Morphology unit, from the Faculty of Agriculture, Trakia University and 5 nutrias from the zoo of Stara Zagora were sedated (Zoletil 50, Virbac, France).

\section{Methods:}

1. Method of interviewing:

a. with hunters

b. with farmers

2. Method of photography - capturing of objects from the habitat of nutrias, making photos of body parts of alive, but sedated nutrias in the zoo of Stara Zagora, capturing of elements of trated skulls of nutria.

3. Craniometric method - studing the volume of the nutria cranial cavity (27). The volume of the cranial cavity of 15 skulls of nutria was measured. These skulls were from Morphology unit, Faculty of Agriculture, Trakia University.

\section{RESULTS AND DISCUSSION}

Information about free-living nutria in the lake of Pastren village was received by the farmer and concessionaire of the lake close to the village. According to him, nutrias have settled here from 4-5 years and have not been more than 12-15 of them. They have been rarely seen swimming in the mirror of the lake. They inhabited the narrowed part of the lake, overgrown with reeds and in the even the animals reached the feeder for fish, where farmers were feeding the fish with grains. In winter, when the lake was frozen, nutrias were observed to cross on the ice, to reach the fish feeder.

Nutrias cleaned from reed almost the entire perimeter of the lake, except the "sleeve", where according to the farmer were the holes for their lairs. The owner told about damage to wheat and barley in lands near the dam, but he said they were not large in comparison to the damage caused by migratory geese and ducks.

Zoo experts from Stara Zagora, informed us that during the winter period nutrias at the zoo have housed under natural temperature. At very low temperatures in winter, some animals get frostbites in peripheral parts of the body, most often in the tail (Figure 2).

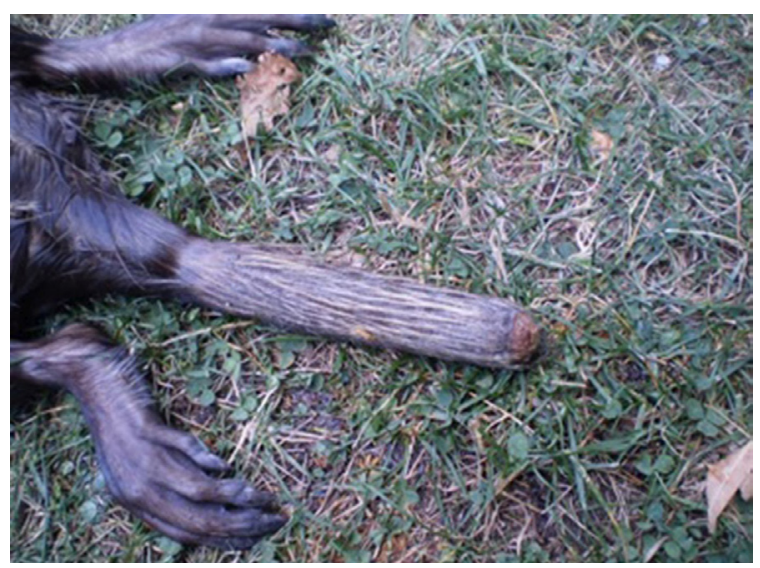

Figure 2. Partial necrosis of nutria tail due to frostbite.

When inspecting the dam of Pastren village, it is clear that it is inhabited by nutria. The effect of their activity is mostly positive concerning the cleaning of the periphery of the lake from reeds and minor damage to winter crops.

Locals informed us of the presence of nutria in some irrigation canals between Pastren village and Badeshte village. When researching the field we found entrances to shelters in the given area of Pastren village (Fig. 3). When studing the habitats close to the irrigation channel, we met local people. They told us that they had seen nutrias (1520 animals) outdoors, which quickly retreated when approaching people. According to us the animals have entered agricultural land to 
look for food. The fact that they had fastly retreated when approaching people and machines, proved that they were timid. That is in accordance to the published description (14).

In our studies (Fig. 3) in the lands between Badeshte village and Pastren village, close to the irrigation canal, we found that in same places it was dry and that there were new traces of habitat. That could be explained by the description, that in natural environment the shelters of nutria are not inconstant (15). The exits of their shelters resembled those, which are described by (13). They were living in holes, deep from 2 to 3 metres, which were digging near the water. The exits were at the water level and structured so as to be not flood. (Figure 3).

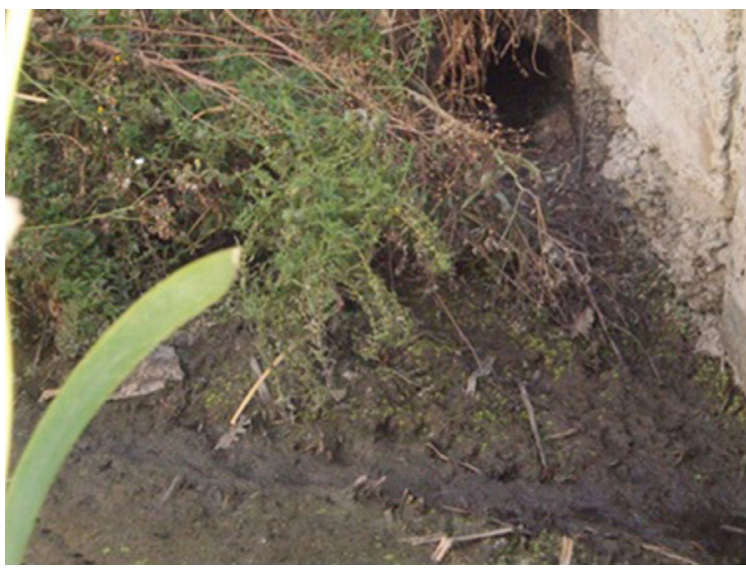

Figure 3. Entrance of the lair of nutria.

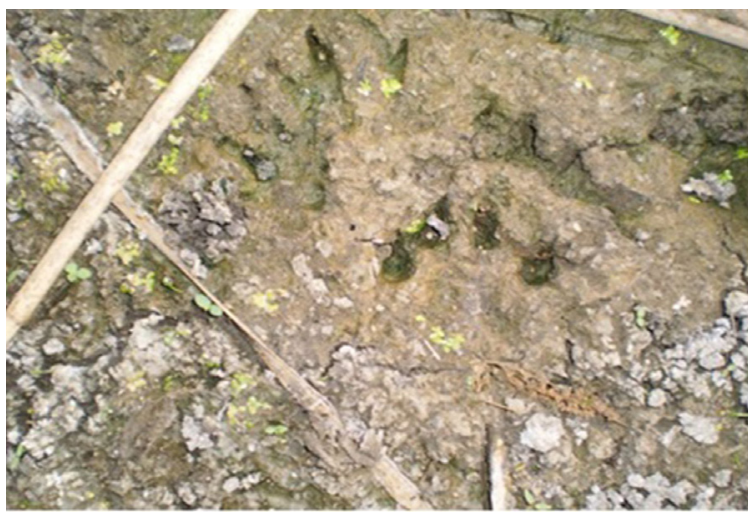

Figure 4. Footprints of pectoral and pelvic limbs.
Close to their lairs were found fresh traces of habitation (Figure 4). They are the best indicators of the presence of nutria. In their habitats were found traces of thoracic and pelvic limbs (23). By established in the mud traces, we claim that the animals are several. Reason for this gave us the differences in size and depth of the footprints.

Found by us feces, floating in the water and mud were typical of nutria, which were identified by us, supported the researches (23) (Figure 5).

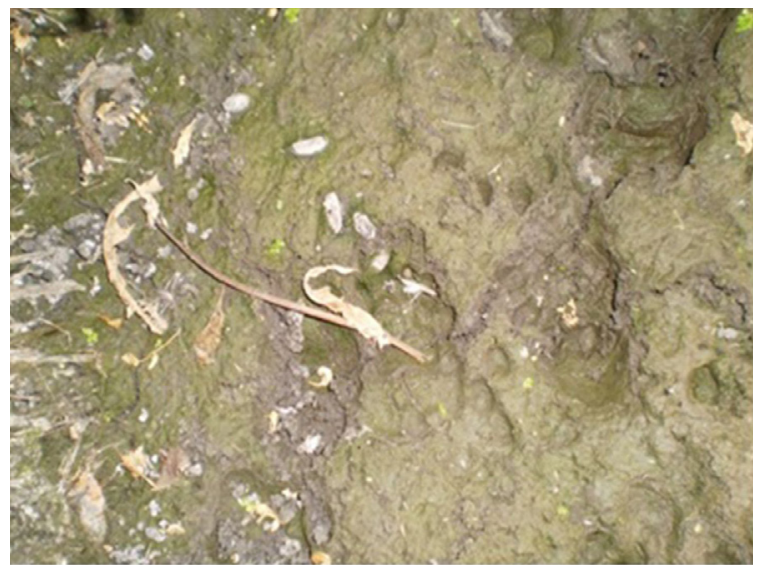

Figure 5. Faces and footprints of nutria.

By the results, we can conclude that nutrias in the studied area have a high ecological plasticity and adaptability for living and feeding in areas under increased anthropogenic pressure and do not cause serious damage to the environment.

We claim that the pectoral limbs are also with five fingers, in comparison to the published data that the pelvic limbs are with five fingers, and the pectoral limbs are with four fingers (13) (Figure 6).

The relatively large size of the brain, respectively larger marrow cavity, is a prerequisite for better behavioral adaptability (28). Relatively larger brain provides an advantage regarding survival of mammals in a new environment. 


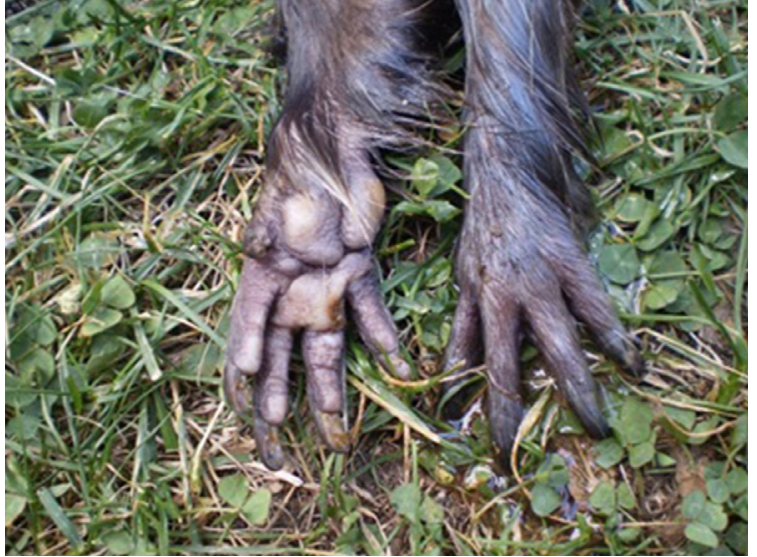

Figure 6. Fingers of the pectoral limb of nutria.

When examining the volume of the cranial cavity (Figure 7 and Figure 8) of the nutria, we received that the average volume was $14.71 \pm 0.8 \mathrm{~cm} 3$. It is much smaller than that of the jackal $-55.3 \mathrm{~cm} 3$ (29) and of the fox $-46.2 \mathrm{~cm} 3$ (29). The average mass of the carcass of the jackal and the fox are $9.51 \mathrm{~kg}$ for the jackal and $5.26 \mathrm{~kg}$ for the fox (30). Due to similar carcase weight of nutria (8-10 $\mathrm{kg}$.) we can assume that the volume of the cranial cavity in nutria is 3.76 times smaller than that of the jackal and 3.14 times smaller than the fox $(11,12)$.

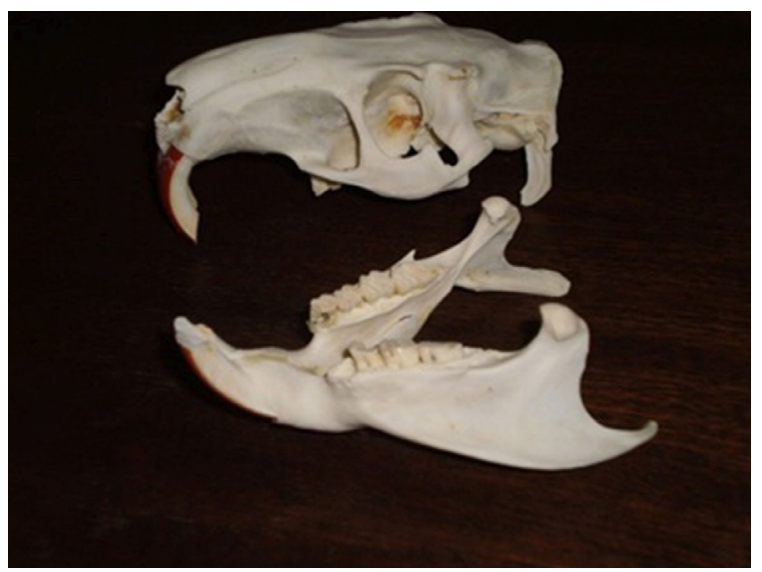

Figure 7. Scull of nutria.

Probably the evident difference in the volumes of the cranial cavities of nutria and the carnivores listed bellow is due to differences in the type of their food and their way of life.

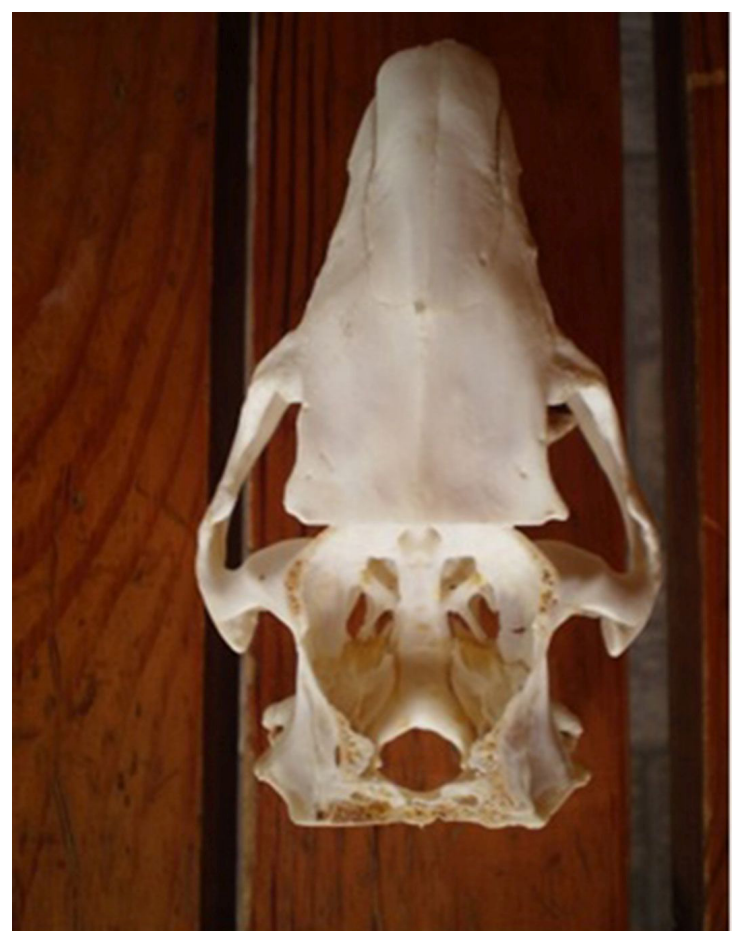

Figure 8. Dorsal view of nutria brain cavity.

As a result of the conducted literature and field research on the biology of nutria in Stara Zagora, as well as the study of the cranial cavity of nutria, we present conclusions, which in a comparative manner (with other authors) determine the significance of the results.

\section{CONCLUSIONS}

1. In the southern part of Stara Zagora region are found data for the presence of nutrias.

2. In the lands between Badeshte and Pastren village are found traces of live activity of nutrias, as entrances of shelters, footprints of pectoral and pelvic limbs and feces.

3. Nutrias have not constant habitats and they migrate depending on the food environment and the water level in the bassins.

4. In the study we did not find data for damages of the environment. 
5. The study showed that the result of the live activity of the nutrias is positive, concerning the cleaning of the water areas from plants.

6. Compared to the published data, that the pelvic limbs have five fingers, and the pectoral limbs are four-fingered (13), we claim that tha pectoral limbs are fivefingered.

7. The obvious difference in the volumes of the cranial cavities of nutria and jackal is due to the differences in the food type and the way of life.

\section{REFERENCES}

1. Aliev E. Numerical changes and the population structure of the coypu, Myocastor coypus (Molina, 1782), in different countries. Seaugetierkunkliche Mitteilungen. 1967; 15: 238- 242.

2. Carter J, Leonard P. A Review of the Literature on the Worldwide Distribution, Spread of, and Efforts to Eradicate the coypu (Myocastor coypus). Wildlife Society Bulletin. 2002; 30, (1): 162-175.

3. Bertolino S, Ingegno B. Modelling the distribution of an introduced species: The coypu (Myocastor coypus) (Mammalia, Rodentia) in Piedmont region, NW ItalyItalian Journal of Zoology. 2009; 76, (3): 340-346.

4. Invasive Species Specialist Group. 100 of the world's worst invasive alien species. 2000; www.issg.org

5. Mann G. Los pequenos mamifers de Chile. 40, p. 342. Editorial de la Universidad de Concepcion, Chile; 1978.

6. Peshev Tc, Peshev D, Popov V. Mammalia, C. Fauna Bulgarica, 27. p. 632. Sofia:Academic Publishing „Marin Drinov; 2004. (In Bulgarian language, with English summary).
7. Popov V., Sedefchev A. 2003. The mammals in Bulgaria. Vitosha, Sofia. 290 p. (In Bulgarian).

8. Mihajlov H, Stoyanov S. 2001. Hunting birds and mammals in Bulgaria. Pensoft. p. 208. (In Bulgarian).

9. Gruychev G. New record of nutria (myocastor coypus, molina, 1782) downstream of the maritsa river in Bulgaria. Forestry ideas. 2012; 18, (1): 110-112.

10. Tzekova I. Investigation of the distribution and ecology of the nutria (Myocastor coypus) in Bulgaria. Bachelor degree, Faculty of Biology, Plovdiv University; 2016.

11. Hristov St. The beauty nutria, DUMA newspaper, 26/03/2011, No 70; 2011. http:// www.duma.bg/node/12636

12. The Louisiana Department of Wildlife and Fisheries. Nutria Biology. Scientific classification; 2007. www.nutria.com/ biology

13. Markov G. Mammals. p. 157. Sofia: Science and Art; 1988.

14. Hunter.bg. Nutria. 30.07.2009. http:// www.hunter.bg/nutriia-66.html

15. Nestorova D. Nutrias, p. 150, 50th illustration. 2008. http://www.e-reading. club/bookreader.php/84073/Nesterova

16. Gosling L. The coypu in East Anglia. Transactions of the Norfolk and Norwich Naturalists' Society. 1974; 23: 49-59.

17. Evans J. About nutria and their control. United States Bureau of Sport Fisheries and Wildlife 1970; 86: 1-65.

18. Atwood EL. Life history studies of nutria, or coypu, in coastal Louisiana. The Journal of Wildlife Management. 1950; 14: 249-265.

19. Kilner NW, Linscombe G, Pamsey PR. Nutria. In: Novak M, Baker JA, Obbard 
ME, Malloch B, editors. Wild furbearer management and conservation in North America Toronto, Canada. p. 326-343. Ontario: The Ontario Trappers Association, Ontario Ministry of Natural Resources; 1987.

20. Dwight J, LeBlanc. Nutria. Prevention and control of wildlife damage. Internet Center for Wildlife Damage Management. 1994; B71-B80.

21. El-Kouba N, Marques S, Pilati C, Hamann W. Presence of fasciola hepatica in feral nutria (Myocastor coypus) living in a public park in Brazil. Journal of Zoo and Wildlife Medicine. 2009; 40: 103-106.

22. Gosling L, Baker S. Planning and monitoring an attempt to eradicate coypus from Britain. Symposia of the Zoological Society of London. 1987; 58: 99-114.

23. Gosling L, Baker S. The eradication of muskrats and coypus from Britain. Biological Journal of the Linnean Society. 1989; 38: 3951.

24. Shterev Sht. Nutria in the river Banska! Haskovska Maritsa. 16/01/2014. http:// haskovo.marica.bg/

25. Vesti. BG. Family of nutrias cleaned a channel. 24th of February. 2015. http://www. vesti.bg/bulgaria/obshtestvo/semejstvonutrii-pochisti-napoitelen-kanal-6032185

26. Newspaper "Sega". A nutria was hunted close to Stara Zagora. No 5059 (184), 12 /08/ 2014. http://www.segabg.com/article. php?id=712103

27. Mihaylov R, Dimitrov R, Raichev E, Kostov D, Stamatova-Yiovcheva K, Zlatanova D, Bivolarski B. Morphometrical features of the head skeleton in Brown Bear (Ursus arctos) in Bulgaria. Bulgarian Journal of Agricultural Science. 2013; 19, (2): 331337.
28. Sol D, Bacher S, Reader S, Lefebvre L.. Brain size predicts the success of mammal species introduced into novel environments. The American Naturalist. 2008; 172, (Suppl. 1): 6371 .

29. Mihaylov R, Dimitrov R, StamatovaYovcheva K, Yovchev D, Radev V, Slavov T. Comparative Morphometric Analysis of the Skull of Some Canidae Species in Bulgaria. Journal of Agricultural science and Forest science. 2014 ; 13, (1-2): 12-21.

30. Raichev E. Food spectrum, morphological features and parasitological status of the fox (Vulpes vulpes), jackal (Canis aureus), wild cat (Felis silvestris) and marten (Martes foina). PhD Dissertation. Trakia University, Stara Zagora, Bulgaria; 2002. 